\title{
Regulation of Community Participation in Management Buffer Zone
}

\author{
Prijo Dwi Atmanto ${ }^{1}$, I Gusti Ayu Ketut Rachmi Handayani ${ }^{2}$, Hartiwiningsih ${ }^{3}$, Lego Karjoko ${ }^{4}$. \\ ${ }_{1,2,3,4}$ Universitas Sebelas Maret, Surakarta, Indonesia \\ prijodwiadmanto@student.uns.ac.id
}

\begin{abstract}
This research examines the regulation of community participation in the management of buffer zones. The research method used is normative legal research with a conceptual approach. Research findings are that there are still many obstacles and obstacles in implementing the policy of community participation in the management of buffer zones as stipulated in the laws and regulations which are not optimal in realizing a sense of social justice in the community or ecological justice and the need to immediately issue implementing regulations of several laws and regulations and stipulation Regional Regulations related to community participation as a manifestation of Indonesian society's 'cooperation' culture to create a just and prosperous society.
\end{abstract}

Keywords-Community, Participation, Ecological.

\section{INTRODUCTION}

The mandate of the 1945 Constitution specifically Article 33 paragraph (3) which reads: "The earth and water and natural resources contained therein are controlled by the State and used for the greatest prosperity of the people" is a manifestation of the State's commitment to regulate the people to realize the ideals of the Indonesian people towards a just and prosperous society. Indonesia's abundant natural resources that are spread out from Sabang to Merauke should be managed as well as possible so that there will be no exploitation of natural resources by groups of people or forest encroachment by communities around protected areas or in buffer zones.[1]

The majority of the people in the buffer zone utilize the natural resources around them to make ends meet. Adaptation behavior to the environment where it lives causes the exploitation and exploration of natural resources which not a few causes environmental damage either intentionally or unintentionally. Legislation relating to the environment and spatial planning can be violated and cause dealing with law enforcement officials if law enforcement is carried out.[2] Anticipating a conflict of interest and creating a balance between the government, the business world, and the community in utilizing natural resources, the role of the central government, regional governments, and the community which include individuals, businesses, and non-governmental organizations are needed to follow authority, duties, and rights and their respective obligations in the management of buffer zones to strengthen the existence of protected areas from activities that cause environmental degradation.[3]

Various cases that occur due to environmental damage in protected areas and buffer zones are mostly done by the community. Regarding this environmental damage, the Directorate General of Law Enforcement of the Ministry of Environment and Forestry, which was reported in the newspaper. tempo.co stated that it had focused on cracking down on illegal logging in the past year: "In this year, the Ministry received 1,426 complaints about various types of environmental damage that occurred throughout Indonesia." This data shows that acts of encroaching and/ or exploiting/ exploiting natural resources without permission and violating laws and regulations are still relatively common among the people, especially around protected areas. Communities in buffer areas are hereditary and continue to use protected areas as militaries for their lives and lives, even though consciously or unconsciously these actions can damage the environment.[4]

The buffer zone as a fortress for the protection and preservation of protected areas will intersect with several problems. The problems that arise from the description above are, what are the obstacles and obstacles faced in implementing the implementation of community participation policies in the management of the buffer zone and how should the community participation policy process in managing buffer zones be arranged to create a just and prosperous society.[5]

That citizen participation is a categorical term for citizen power. Arnstein stated that: "Citizen participation is a categorical term for citizen power. It is the redistribution of power that enables the have-not citizens, presently excluded from the political and economic processes, to be deliberately included in the future. Is the strategy by which the have-nots join in determining how information is shared, goals and politics are set, tax resources are allocated, programs are operated, and benefits like contracts and patronage are parceled out. In short, it is how they can 
induce significant social reform which enables the share in the benefits of the affluent society.[6]

Poster argues that participation without the redistribution of power is an empty and frustrating process for those who are powerless. This empty ritual allows the holder of the power to claim that all parties are considered, but can also make that only a few parties benefit. The levels of participation according to Arnstein, namely the lowest rung are (1) manipulation and (2) therapy. These two steps describe the level of non-participation created by several parties to replace participation in fact. Steps 3 and 4 rise to the level of tokenism that allows the poor to hear and speak:

(3) member information and (4) consultation. [7]

When citizens are allowed to put forward ideas at the level of total participation by the holders of power, they can indeed hear and be heard. But in this condition, citizens do not have the power to ensure that their views will be heeded by the authorities. The fifth rung, Placation, plaque, or appeasement, is only a tokenism at a higher level because basic rules allow the poor to give advice, but retain the right of the holder of the power to continue making decisions. Whereas the higher level of citizen participation ability is in decision making. Citizens can enter into (6) Partnerships that enable them to negotiate and engage in transactions with traditional power holders. On the top step, (7) delegated power (delegated power) and (8) Citizen control (Citizens' control), the poor get most of the decision-making seats or full managerial power.[8]

In the opinion of Robert Chambers, there are 3 models of participation proposed by experts. Other opinions such as Kenji and Greenwood divide participation levels into 5 levels. VeneKlasen and Miller argued by dividing the number of participants into 7 levels From the eight steps of participation from Arnstein, he gave an understanding that there was enormous potential for the manipulation of community participation programs into a way to defraud (devious methods) and reduce the ability of the community to influence the decision making process. [9]

Hessel further quoted Hicks' opinion that in formulating a sense of responsibility as the quality of society to develop independently, when the person concerned consciously and freely chose and agreed on everything, absorbed a value, or accepted a task.[10] Ecological justice is social justice that places environmental sustainability as the main point. Ecological justice cannot be separated from the existence of sustainability in the lives of present and future generations. The concept of sustainable development is also an effort to obtain equitable justice for current and future generations.[11]

Rawls in Brian Baxter rejects the idea that the relationship between humans and non-human organisms can be properly brought under the heading of 'justice' even though he is equally clear that humans have some moral responsibility for non-human life.[12] The concept of social justice is part of the concept of ecological justice and if it is linked to the theory of community participation in the management of buffer zones is very relevant to maintaining the preservation of protected areas.

\section{RESEARCH METHOD}

The type of research used is normative or doctrinal legal research. Legal material consists of primary legal material, secondary legal material, and tertiary legal material. The primary legal materials legal material consisting of legislation based on its hierarchy. Secondary legal material is legal material consisting of textbooks written by influential legal experts (de herseende leer), legal journals, scholars' opinions, legal cases, jurisprudence, and results in the current symposium related to research topics.[13]

\section{FINDINGS AND DISCUSSION}

\section{Community Participation in Management of Buffer Areas}

The buffer zone needs to be managed well by the government by involving individuals and communities. Wild and Mutebi termed buffer zones with buffer zones and argued that buffer zones are believed to reduce negative impacts, and increase positive impacts, both from conservation areas on the surrounding communities and vice versa. A buffer zone is an area adjacent to a conservation area whose land use is limited to provide an additional layer of protection for the conservation area and at the same time benefit the surrounding community.[14]

Citizen participation is a categorical term for citizen power. Citizen participation is a redistribution of power that enables poor citizens, who are not currently involved in the political and economic process, to be deliberate involved in the future. In short, citizen participation is a tool that can encourage significant social reforms that enable the poor to get a share of the benefits of a prosperous society.[11]

The manifestation of community participation in the management of buffer zones is in the form of community participation to preserve protected areas by empowering the surrounding environment, namely strengthening buffer zones by managing the environment as Lothar Gundling argues in Koesnadi Hardjasoemantri as follows:[15]

a. Give information to the government;

b. Increase the willingness of the community to accept decisions, 
c. Helping legal protection implies that a decision can have major consequences, it is expected that everyone who will be affected by the decision needs to be notified and have the opportunity to raise objections.

d. Democratizing decision-making, means that community participation is seen to help the State and its institutions to carry out their duties [8].

In connection with community participation in the management of buffer zones, the community can play a role following their abilities for the benefit and preservation of the environment.

\section{Arrangement of Community Participation in Management of Buffer Areas}

Regulations governing community participation in the form of community participation in managing buffer zones are included in Law Number 5 of 1990 concerning Conservation of Living Natural Resources and their Ecosystems, in Chapter IX concerning the Participation of People. In the conservation of living natural resources and their ecosystems, the Government is directed and mobilized through activities that are useful and effective. The law also explains that further regulation is needed by Government Regulation.[16]

Law Number 41 of 1999 concerning Forestry in Chapter $\mathrm{X}$ Article 68 concerning community participation, affirms that the community has the right to enjoy the quality of the environment produced by the forest, the community can utilize the forest and forest products following applicable laws, know the designation plan forests, the use of forest products, and forestry information, providing information, advice, and considerations in forestry development, and supervising the implementation of forestry development both directly and indirectly. However, of course in its implementation, it requires implementing regulations for the operationalization of this Act in the form of Government Regulations. Regulation of the Minister of Environment and Forestry of the Republic of Indonesia Number: P.43/ MENLHK/ SETJEN/ KUM.1/ 6/2017 concerning. Empowerment of Communities around Natural Reserved Areas and Nature Conservation Areas.[17]

One of these Ministerial Regulations regulates the form of Community Empowerment. The form of community participation in the form of community empowerment includes community empowerment around Nature Reserve and Nature Conservation Areas, including developing Conservation Villages, granting access, facilitating partnerships, granting licenses to operate natural tourism services, and constructing tourist lodges. The provisions of the existing legislation if it can be implemented properly and correctly means that community participation in the form of community participation and empowerment are successful not only 'law in the books' but 'law in action.[18]

\section{Implementation of Community Participation Policy Implementation}

Based on the existing regulations and associated with the theory of participation and the theory of ecological justice and social justice theory that has been stated earlier, it turns out that the policies outlined in the legislation when associated with data on environmental damage and the reality that occurs such as a case of wood theft by a grandmother named Asyani who was sentenced to one year in prison with a trial period of one year and three months and a fine of nine million rupiahs one-day subsidiary was an incident that hurt a sense of justice in the community. Only for stealing firewood in a protected area.[19]

This example is a handful of problems encountered in managing buffer zones. Not to mention the occurrence of flash floods and landslides shows the community participation is still not optimal in the form of community participation and community empowerment in the buffer zone. Communities in buffer zones such as 'spectators' in managing buffer zones mean that not all of them understand the function and role of the community in participating in managing buffer zones based on cooperation culture to realize social justice while also paying attention to nonhuman justice. The terms 'law in the book' and 'law in action are two opposite sides of a coin but are attached. The gap between Das Sein and Das Sollen needs a solution.[20]

In line with the Legal, System Theory put forward by Lawrence Friedman, which was rewritten by Budi Riyanto that law as a system has 3 elements, namely (a) the structure of the legal system (Structure of Legal System) consisting of law-making institutions, the operation of the law, (b) substance of the legal system (the substance of legal system) in the form of legal norms, legal regulations, including patterns of community behavior that are behind the legal system and (c) the legal culture of society (legal culture), such as values, ideas, hopes and beliefs that manifest in people's behavior. The law can run well if These three components can work together so there is a need for coordination and participation of all stakeholders.[21]

\section{Efforts in Improving the Implementation of Community Participants}

In the context of forest management based on community participation or roles, the basic principles that must be developed are: 
a. The principle of Co-Ownership is that a forest area is a shared property that must be protected together, for that there are community rights in it that must be recognized but also the protection that must be done together;

b. The principle of Co-Operation/Co-Management is that joint ownership requires forest management to be carried out together with all community components (stakeholders) consisting of government, communities, and NGOs that must work together.

c. The principle of Co-Responsibility is that the existence of forest areas is a shared responsibility because the management of forest areas is a common goal.

Community participation in the management of buffer zones experiences many obstacles and obstacles from the lack of an optimal legal system in implementing buffer zone management. This means that there needs to be strengthening for the community in the buffer zone which starts from strengthening the organization, namely the need for a review of legislation in terms of participation such as the need for the issuance of Government Regulations on participation or community participation in the field of Forestry and Conservation of Living Natural Resources and Ecosystems, increasing community participation by providing socialization the importance of strengthening the management of buffer zones to protect protected area ecosystems to remain sustainable and not cause environmental degradation and by striving to achieve ecological justice.[22]

If the empowerment of the surrounding community by promoting the culture of local wisdom, government policy will be acceptable to all parties. Strategic efforts that can be made to create a just and prosperous society by paying attention to aspects of social justice and ecological justice are to make policies by the needs of the community related to the management of buffer zones. Therefore, the regulation of laws and regulations by empowering the role of local governments in managing the buffer zone together with the community in the buffer zone by implementing the preparation of regional regulations on the buffer zone. In addition, it is necessary to determine the priority of implementation in the management of the buffer zone by promoting: socialization to the community in the buffer zone.[23]

\section{CONCLUSION}

The community around the buffer zone plays a very big role in maintaining the preservation of the nature conservation area and the Nature Reserve Area, the obstacles faced in community participation in the management of the buffer zone are (i) lack of community understanding regarding participation in the form of community participation and empowerment in the buffer zones. (ii) the community has not been optimally involved in the management of the buffer zone. (iii) the regulations are still too restrictive regarding the management of buffer zones and not all regulations relating to natural resources have been issued implementing regulations so that they appear barren. (iv) the absence of legislation in the form of Regional Regulations as a basis for managing buffer zones by promoting local wisdom. While the steps that must be taken by the government in the context of policy evaluation are: determine the policies in accordance with the needs of the community related to the management of the buffer zone, establishing priorities for implementation in the management of the buffer zone by promoting: socialization to the community in the buffer zone, granting community empowerment participation and participation so that it is expected that there are steps that elevate the social degree of the community with participation following the concepts of co-ownership, co-operation/ co-management, and co-responsibility, namely to a sense of responsibility.

\section{REFERENCES}

[1] M. Roestamy, "Model Land Supply for Land Bank to House Application Martin,” Bestuur, vol. 7, no. 2, 2019.

[2] A. Jumari, "Potensi Pelanggaran Pengelolaan Limbah Bahan Berbahaya dan Beracun," J. Best., vol. 7, no. 2, 2019.

[3] Yusriando, "Konstruksi Sistem Jaminan Sosial Nasional Bidang Kesehatan Yusriando," Bestuur, vol. 7, no. 2, 2019.

[4] U. K. Mishra and A. Negi, "Transgender and the Right to Employment in India: Analysing the Trajectories of Discrimination," Bestuur, vol. 9, no. 1, pp. 34-43, 2021.

[5] L. C. Lintang, Adriano Martufi, and J.W. Ouwerker, "The Alternative Concepts of Blasphemy Law in Indonesia: Legal Comparison with Ireland and Canada," Bestuur, vol. 8, no. 2, pp. 121-128, 2020.

[6] S. R. Novikasari, D. Q. Ly, and K. Gershaneck, “Taxing Micro, Small and Medium Enterprises in Yogyakarta: Regulation and Compliance," Bestuur, vol. 9, no. 1, 2021. 
[7] M. A. Mohd Sani and D. D. Abdul Hamed Shah, "Freedom of Religious Expression in Malaysia," J. Int. Stud., pp. 33-50, 2020.

[8] S. A. Estikomah, "Aspek Hukum Import Sampah Plastik," Bestuur, vol. 7, no. 2, p. 41, 2019.

[9] A. A. Hamzana, "Pelaksanaan Standarisasi Pelayanan Pariwisata Halal dalam Pengembangan Pariwisata di Nusa Tenggara Barat," Pena Justisia Media Komun. dan Kaji. Huk., vol. 17, no. 2, pp. 1-16, 2018.

[10] B. Prasetyo, I. G. A. K. R. Handayani, A. Sulistyono, and L. Karjoko, "Legal framework for social security state civil apparatus," Int. J. Adv. Sci. Technol., vol. 28, no. 20, pp. 310-313, 2019.

[11] I. Gusti Ayu Ketut Rachmi Handayani, G. Gunarto, A. Mashdurohatun, I. Gusti Putu Diva Awatara, and F. U. Najicha, "Politic of legislation in Indonesia about forestry and the mining activity permit in the forest area of environmental justice," Journal of Engineering and Applied Sciences, vol. 13, no. 6. pp. 1430-1435, 2018.

[12] A. K. Jaelani, I. G. A. K. R. Handayani, and L. Karjoko, "Development of tourism based on geographic indication towards to welfare state," Int. J. Adv. Sci. Technol., vol. 29, no. 3 Special Issue, pp. 1227-1234, 2020.

[13] R. D. Luthviati, "The Role of Local Governments in the Defense of Leading Products Resti," J. Best., vol. 8, no. 2, pp. 121-128, 2020.

[14] Yuliandri, G. A. K. R. Handayani, T. Prasetyo, K. Seregig, and H. Tegnan, "Retributive justice theory and the application of the principle of sentencing proportionality in Indonesia," J. Leg. Ethical Regul. Issues, vol. 21, no. 4, pp. 1-8, 2018.

[15] I. G. A. K. R. Handayani, H. Glaser, S. Monteiro, E. D. Kusumawati, A. K. Jaelani, and F. U. Najicha, "Water availability in the framework of environmental justice: reconstruction of municipal waterworks (pdam) regulations," Int. J. Business, Econ. Law, Vol. 20, Issue 4 2019, vol. 20, no. 4, pp. 51-55, 2019.

[16] I. Iswantoro, "Strategy and Management of Dispute Resolution, Land Conflicts at the Land Office of Sleman Regency," J. Hum. Rights, Cult. Leg. Syst., vol. 1, no. 1, pp. 1-17, 2021.

[17] A. Ma, "Legal Aspects of Environment in Indonesia : an Efforts to Prevent Environmental Damage and Pollution," J. Hum. Rights, Cult. Leg. Syst., vol. 1, no. 1, pp. 18-30, 2021.

[18] A. K. Jaelani and R. D. Luthviati, "The Crime Of Damage After the Constitutional Court's Decision Number 76 / PUU-XV / 2017," J. Hum. Rights, Cult. Leg. Syst., vol. 1, no. 1, pp. 31-41, 2021.
[19] R. Res, "Implementation of Parate Executie Object of Liability Juridical Overview of Mortgage," J. Hum. Rights, Cult. Leg. Syst., vol. 1, no. 1, pp. 42-53, 2021.

[20] Syahlan, "Effective and Efficient Synchronization in Harmonization of Regulations Indonesia," J. Hum. Rights, Cult. Leg. Syst., vol. 1, no. 1, pp. 54-70, 2021.

[21] R. I. Ichlas, "Questioning the Independence of Media Coverage in the 2019 Elections," J. Best., vol. 8, no. 1, 2020.

[22] W. N. Hanum, "Setting of Earth Oil Management in Old Wells Based on the Principle Social Justice," Bestuur, vol. 8, no. 2, p. 70, 2020.

[23] K. Intaniasari, "Gross Split Contract Framework Regulation on the Caring for People," Bestuur, vol. 8, no. 2 , p. $96,2020$. 